\title{
Investigating Teachers' Perceptions and Instructional Practices Regarding Form- Focused Instruction of Speech Acts in Iranian EFL Context
}

Melahat Amir Jahansouz Shahi

Islamic Azad University Varamin-Pishva Branch

Neda Gharagozloo ( $\square$ N.gh@iauvaramin.ac.ir)

Islamic Azad University Varamin-Pishva Branch https://orcid.org/0000-0002-4443-4033

Reza Raissi

Islamic Azad University Varamin-Pishva Branch

Original article

Keywords: Form- focused instruction, Speech acts, Teachers' instructional practices, Teachers' perceptions

Posted Date: June 7th, 2021

DOI: https://doi.org/10.21203/rs.3.rs-572446/v1

License: (c) (i) This work is licensed under a Creative Commons Attribution 4.0 International License. Read Full License 


\section{Abstract}

This study aims to investigate Iranian EFL teachers' perception and instructional practices towards formfocused instruction of speech acts specifically request, apology and invitation. To this aim, through sequential explanatory mixed methods design the researchers used criterion sampling and 30 English language instructors in Islamic Azad University (IAU) of North Tehran Branch served as the subjects. To attain general perception and teaching practices of instructors towards form-focused instruction of speech acts, they were asked to answer a pragmatic questionnaire. Besides, in order to achieve an enhanced awareness concerning instructors' perceptions and practices regarding form-focused instruction a semi-structured interview was conducted for the same 30 English language instructors. Finally, six classes were observed by the investigators through convenience sampling. Likewise, through the triangulation approach, the investigators studied and merged the required data. The statistical results of the quantitative and qualitative data analysis revealed that form-focused instruction of speech acts is mostly focused by the Iranian EFL instructors. Most of them agreed with the use of explicit strategies for instructing request, apology and invitation speech acts rather than implicit strategies. Additionally, the explicit strategies were used by most of the instructors in EFL classes. The results of the current study are beneficial for syllabus directors and scholastic administrators to have a different outlook towards the curricula and textbooks' content, particularly for EFL settings.

\section{Introduction}

Pragmatics is a problematic area to acquire for second/foreign language learners. Irrespective of the linguistic, second/foreign language learners occasionally find it challenging to understand the proposed connotation expressed via the speech act because it is mainly determined by the context (Rajabia, Azizifara, \& Gowhary, 2015). Based on Kondo (2008) the suitable practice of language is complicatedly linked to cultural tenets and situations; thus, it is one of the key reasons about the difficulty to obtain functional competence. Here, there are difficulties concerning the application of English in the EFL classes (Kondo, 2008). Concerning this issue, Nurani (2015) highlighted the problem about the use of speech acts in Indonesian EFL context. She stressed the inappropriate use of the speech acts uttered in classes led to misunderstanding in the class setting. In such a context learners may have diverse understandings of a simple exclamation assumed by the teacher (Nurani, 2015).

In order to solve the pragmatic challenges and enable learners to interact effectively, several investigations have been conducted (Martínez-Flor \& Usó-Juan, 2010). More investigations have concentrated on syntactic mistakes as the basis of communication failure (Ansarin \& Mohamadi, 2013). On the other hand, appropriateness of errors can have more detrimental effects than grammatical faults which may categorize the non-native speaker equally unhelpful, impolite and aggressive (Crandall \& Basturkmen, 2004). Many second/foreign language learners seem to struggle to display pragmatic maturity once it appears in real-life circumstances, and the situation is also valid for fluent students (DeCapua \& Dunham, 2007; Hinkel, 1997; Martínez Flor, 2005; Pishghadam \& Sharafaddini, 2011). 
In educational contexts, training pragmatics and its elements for developing learners' pragmatic knowledge have been valued and the dominant reason about considering pragmatic knowledge is improving learners' knowledge in this regard. Further, speech acts enhanced researchers' attention in the arena of interlanguage pragmatics (ILP) (Alco'n \& Pitarch, 2010).

Based on previous investigations (Bardovi-Harlig, 2001; Halenko \& Jones, 2011; Kasper, 2001; Olshtain \& Cohen, 1990). learners who took instructional courses in pragmatics, accomplished more than the other learners. In this regard, supported output offers the learners desirable feedback and provided further chances to exercise both explicit and implicit directions in EFL setting. Besides, the instructor may offer some explanations to the class with explicit instruction (Alcón Soler, 2002; R. Schmidt, 1993). Through explicit tactic the brain explains the difficulties deliberately and tries to examine associated memory. Learners study better when they need to study from rational involvements rather than perceptual comparisons (R. Schmidt, 1990). In this regard, Rajabia, Azizifara, and Gowhary (2015) emphasized the consequence of explicit teaching on pragmatic act of learners (Rajabia et al., 2015). The findings showed that explicit teaching is an effective method to improve the pragmatic capability of L2 learners and the general suitability of speech actions. Concerning the implicit instruction, Alerwi and Alzahrani's (2020) investigation highlighted the dominant role of situational comedy to develop Saudi EFL learners' speech acts of request, apology, refusal and compliment (Alerwi \& Alzahrani, 2020). Explicit instruction usually involves defining, illustrating and conversing a target realization and comparison concerning L1 and L2 (Salemi, Rabiee, \& Ketabi, 2012). Dole (2000) described implicit instruction via illustrating the role of the teacher in implicit teaching (Dole, 2000). Based on Dole (2000), implicit guidance positions the instructor as a facilitator. The task of the teacher is to provide a rich background that includes several books for reading, time for reading and writing, and reasons for literacy. Generally, implicit teaching in language teaching has gained not as much of consideration than explicit training and implicit training is different from mere input exposure.

In this realm, request is one of the most problematic speech acts and learners need high levels of suitability and considerable cultural and linguistic skill (Blum-Kulka \& Olshtain, 1984). Consequently, knowing how request speech acts are shaped for EFL learners is an important issue in academic context.

Among other speech acts, apology gained particular consideration in the realm of sociolinguistics (Brown \& Levinson, 1978). According to Goffman (1971) apologies are considered as "remedial interchanges" which target re-establishing communal agreement after an actual or simulated offence has been accomplished (Goffman, 1971). Likewise, an invitation is commonly reflected as a speech act. Based on Searle (1975) speaker's attempt to get the hearer to do something is comprehensive when the inviter openly desires the invitee to attend in an event and is willing to take the invitee's attendance (Searle, 1975).

In a recently-conducted experimental study in Iran, Rajabi and Farahian (2013) identified the effectiveness of instruction on pragmatic competence (Rajabi \& Farahian, 2013). The awareness-raising of the experimental group was enhanced through instruction. The results showed that the group receiving 
awareness-raising treatment outdid the control group. The results of these studies are in line with Fordyce (2014) findings which indicated that both the implicit and explicit groups were better at pragmatic performance than the control group without any treatment. In another conducted research belongs to Farshi and Baghbani (2015), it was revealed that the group with awareness raising instruction outdid the group without the kind of instruction. The researchers concluded that using awareness-raising activities had very great effects on pragmatic production of language learners in EFL contexts.

To address the gap, the current investigation examined the instructors' thoughts, beliefs and practices of unique educational tactics on increasing L2 pragmatic capability and the awareness of instructors to the explicit and implicit presentation of request, apology, and invitation speech acts. The key concern now focuses on the demand of how we can teach this capability in the most successful way, because of the consensus on the need to teach realistic competence. It should be noted that the present study discussed the instructors' perceptions and practices regarding form-focused instruction of speech acts specifically request, apology and invitation in Iranian EFL context.

\section{Literature review}

For many years, getting familiar with grammatical rules and large amount of vocabularies were the main purpose of language teaching. But, gradually it was proved that learners with great success in English grammar and vocabulary were not able to communicate effectively and appropriately in foreign language (Krisnawati, 2011). The objective of defining the development of L2 pragmatic capability in SLA is discussed here by examining the ties concerning SLA and interactive capability, pragmatic ability and teaching L2 pragmatic skills.

In this realm Choraih, Loutfi, and Mansoor (2016) explored the importance of pragmatic competence in English language teaching. They offered evidence that language proficiency could not only be equated with well-formed grammatical skills, but also with how to use them in the target language properly and effectively (Longman. Choraih, Loutfi, \& Mansoor, 2016).

Similarly, Alinezhad (2015) demonstrated that pragmatics should be considered as a subdivision of linguistics and its important role in SL should be considered in academic context. He mentioned that the expansion of pragmatic capability can be established to $L 2$ learners and instructors as the primitive teaching goals. Through using pragmatic competence in English language teaching, learners can understand numerous stages of grammar and functions in an accurate and fluent mode (Alinezhad, 2015).

Concerning this issue, Aufa (2013) investigated the efficiency of DCT (Discourse Completion Task) as an explicit pragmatic teaching to assist second language learners in enhancing their pragmatic competence. The results supported the effectiveness of explicit instruction in some variations of linguistic forms that assisted in improvement of learners' pragmatic competence (Aufa, 2013). 
Besides, Trang Thị Đoan Đặng and Hương Thu Nguyễn (2013) studied the effect of indirect explicit grammar teaching on EFL learners' ability of English language tenses. The outcomes specified that explicit grammar group meaningfully outdid the implicit grammar group concerning the grammatical rules and the oral expertise. Additionally, there was a positive association between the grammar rules and their following practice (Đặng \& Nguyễn, 2013). Similarly, Bakhshayesh and Jafari (2018) investigated the impact of input improvement and explicit teaching on promoting Iranian EFL learners' explicit awareness of present tense and past passive voice. The findings showed the advantage of the explicit teaching in enhancing explicit awareness of passive voice (Bakhshayesh \& Jafari, 2018).

Additionally, Tajeddin and Hosseinpur (2014) highlighted awareness-raising accomplishments as an ameliorative process for learners to acquire socio-pragmatic and pragma linguistic information. They investigated the efficiency of deductive, inductive and L1-based awareness raising on EFL learners' attainment of the request speech act. The findings showed that training meaningfully had positive effect on learners' attainment of the request speech act. Besides, comparison of the task types confirmed that deductive activity was the most operative one (Tajeddin \& Hosseinpur, 2014).

Likewise, the longitudinal research of Ifantidou (2013) verified the efficacy of explicit instruction on the growth of pragmatic competence of learners by analyzing different features of pragmatic capability through the application of various means. Besides, triangulation was an effective approach in this research. The long-term effects of learning in the second group were entirely due to the specific teaching procedures in this investigation (Ifantidou, 2013).

Likewise, Arabmofrad, Derakhshan and Atefinejad (2019), examined the association between Iranian advanced EFL learners' meta-pragmatic consciousness, its features and their overall and definite pragmatic motivation. In this investigation the speech act of refusal was designated as a target speech act. The findings specified that there was a significant relationship between Iranian EFL learners' metapragmatic consciousness and their pragmatic inspiration (Arabmofrad, Derakhshan, \& Atefinejad, 2019).

Similarly, Azarmi and Behnam (2012) examined the capability of the upper intermediate and the intermediate learners in keeping face in diverse complaint circumstances. The results showed that learners in both levels applied diverse sorts of speech acts in each condition. Researchers highlighted that some degree of pragmatic consciousness should be offered at low levels too (Azarmi \& Behnam, 2012).

Based on the previous experiences, most of the studies in the Iranian EFL context focused on learners' perception towards form-focused instruction but teachers' educational perceptions and their practices towards the instruction were rarely considered in the Iranian EFL context. In order to fill the gap in the literature and accomplish the purpose of the study, the following research questions were posed by the researchers:

1. What are the instructors' perceptions towards form-focused teaching of speech acts specifically request, apology, and invitation? 
2. How do the instructors practice form-focused instruction of speech acts specifically request, apology, and invitation in EFL classes?

\section{Methods}

\section{Theoretical framework}

Sperber and Wilson (1986), believe that in relevance theory, pragmatic comprehension varies according to relevance ranging from irrelevance to weak, strong and optimal relevance. It depends on how the listeners or readers process the content of message. According to Schmit (1995), noticing hypothesis referring to pragmatic features of the target language, attracts the attention of learners to these features which influence the development of learners' pragmatic comprehension. Therefore, relevance theory and noticing hypothesis make the theoretical framework of the current research.

\section{Materials and Instrumentation}

In the current study, three instruments were used, namely a pragmatics questionnaire, a semi-structured interview and an observation scheme. The first one was the pragmatics questionnaire adopted from Ji (2007) and Kachru (1992a) then it was adapted by the researchers based on Iranian EFL context. It was applied to evaluate teachers' insights concerning teaching and learning pragmatics and the approaches and procedures they used in their classes (Ji, 2007; Kachru, 1992a). The second instrument was a semistructured interview. The semi-structured interview is a qualitative data collection strategy in which the researcher asks informants a series of predetermined but open-ended questions. And Communicative Orientation of Language Teaching (COLT) observation scheme was used as a third instrument. It was adapted a little by the researchers based on the Iranian EFL context. The COLT is divided into two parts: a macro level part (Part A) and a micro level part (Part B). Part A describes classroom instruction in terms of the types of activities that take place. Merely part A of COLT was applied in this investigation.

\section{Reliability of the instruments}

Besides, the reliability was inspected prior to the administration of the questionnaire. The investigators adapted the survey and randomized the questions in a pilot investigation to define the reliability of the questionnaire. The pilot investigation was performed among $30 \mathrm{EFL}$ instructors. The Total Cronbach's Alpha reliability of the teachers' questionnaire was .802 . It was beyond 0.7 and satisfactory. Based on Dornyei and Taguchi (2010) the index beyond 0.60 is an acceptable quantity (Dornyei \& Taguchi, 2010).

Concerning the observation scheme, the investigators used inter-coder reliability enquiry which was .88 and satisfactory, it indicated the significant agreement between the raters.

\section{Validity of the instruments}

In this study, the KMO of the factor analysis of the instructors' questionnaire was 0.65 , which was above 0.5 and acceptable. In the pilot study, the five Ph.D. professors evaluated face validity of instructors' 
interview questions and classroom observation scheme. The point of view of five academic experts about validity of the observation scheme was $81.5 \%$, and the validity of the interview questions was $82 \%$, which was acceptable.

\section{Participants and Sampling}

Thirty English language instructors from the IAU, North Tehran Branch, were selected as the participants of the present study. In the quantitative phase, criterion sampling was applied. Criterion sampling includes selecting subjects that encounter some prearranged norms (Patton, 2001). The first condition for selecting the subjects was associated with the instructors' field of the study. The second norm was associated with the teaching experience of the instructors. Finally, the third criterion was related to the instructors' professional career.

Firstly, the instructors were asked to contribute to the quantitative phase, the pragmatics questionnaire adopted from Ji (2007) and Kachru (1992a). It was applied to evaluate teachers' insights concerning teaching and learning pragmatics and procedures they used in their classes (Ji, 2007; Kachru, 1992a). Then, in the qualitative phase, thirty English language instructors were requested to contribute in a semistructured interview. The interviews were directed to explore the fundamental rationales of the instructors' outlooks concerning form-focused implementation, as well as their opinions and practices about implicit and explicit teaching of speech acts. Furthermore, six instructors' classes were designated for observation via convenience sampling. The six classes were observed over 8 weeks, once a week during a 90-min instructional period in Islamic Azad University, North Tehran Branch.

\section{Design and Procedure}

To improve the credibility and validity of the examination, the current investigation applied sequential explanatory mixed method design. In this design, the prominence was assumed for the quantitative method since the quantitative data collection arose first in the order and often signified the main feature of the mixed-methods data gathering procedure. The qualitative data collection tracked in the second stage of the investigation. Through the use of triangulation approach, the researchers examined the convergence of evidences from different methods using more than one specific approach of collecting and analyzing data (Wilson, 2014). The researchers used triangulation approach to achieve the intended goals of the investigation. The perceptions and practices of EFL instructors were examined towards formfocused teaching of speech acts in university context. Thirty instructors were requested to complete the questionnaire in order to evaluate their perceptions and instructional practices regarding pragmatics specifically request, apology, and invitation.

The interview with thirty instructors was applied as a second means in this research. The semi-structured interview was conducted to explore instructors' outlook towards pragmatic teaching in the classroom.

Eventually, the researchers observed six classes over 8 weeks, once a week during a 90-min instructional period in Islamic Azad University, North Tehran Branch. The primary goal was to examine how instructors 
communicated pragmatics in their real classes. The observation helped researchers to understand the association between the instructors' perspectives and their classroom performance.

\section{Data collection and Analysis}

This study investigated perceptions and instructional practices of Iranian EFL teachers regarding formfocused instruction of speech acts specifically, request, apology and invitation. Data collection procedures included three phases, namely questionnaire, interview and observation. To this aim, 30 instructors participated in the current study. All of the participants were asked to fill out the questionnaire to evaluate teachers' insights concerning teaching and learning pragmatics and procedures they used in their classes. The second instrument was a semi-structured interview. Thirty instructors were interviewed to gain better information about their perceptions and practices regarding form-focused instruction of speech acts. And Communicative Orientation of Language Teaching (COLT) observation scheme was used as a third instrument to investigate instructional practices of teachers in classes. The quantitative data was analyzed via SPSS software, version 26 , and frequency, percentage, mean and standard deviation were run to fulfill the descriptive analysis section. Concerning qualitative part, the investigators used thematic analysis. According to Ezzy (2002) coding denotes the procedure of "disassembling and reuniting the information" (Ezzy, 2002, p:94). Thematic analysis is a method to analyze the repeated patterns of qualitative data (Braun \& Clarke, 2006).

\section{Results}

In this section outcomes, concerning the quantitative and qualitative stages are presented.

\section{Results of Quantitative Phase}

\section{Questionnaire results}

The questionnaire was adopted from Ji (2007), and Kachru (1992a) then it was adapted by the researchers. The questionnaire used 29 items and was distributed among 30 teachers, who teach in Islamic Azad University, North Tehran Branch. The questionnaire consists of three parts; demographic data (5 items), perceptions towards teaching and learning pragmatics (18 items), and methods and techniques used in classes (6 items) (Ji, 2007; Kachru, 1992a).

According to the results of the present study, Table 4.3, the construct that gained the highest rank in the instructors' questionaire was related to request $(M=4.12, S D=0.45)$. Additionally, the second highest mean index was related to apology $(M=3.97, S D=0.56)$. And finally, the third highest mean index was related to invitation $(M=3.86, S D=0.63)$

\section{Perceptions towards Teaching and Learning pragmatics}

This section presents the findings from the questionnaire data concerning teachers' perceptions towards teaching pragmatics of request, apology, and invitation in the classroom. 
Concerning item 6 "I think the knowledge of how to use request speech act is necessary for EFL learners", all contributors approved or strongly agreed with it. The result is in line with the interview part:

For example, teacher 11 from NB: The inappropriate application of speech act may result in misinterpretation between interlocutors. Learners may have diverse clarifications of a statement. This is caused by the failure of using speech acts in certain situations.

Most of the instructors $66.7 \%$ agreed with item 7 as "I believe learners' consciousness raising of getting information on culture and suitable language practice is more beneficial for learning request speech act", while $33.3 \%$ disagreed with this idea. The result is in line with the findings of interview:

For example, teacher 23 from NB: I think building language awareness help learners to integrate what has been learned with the new information. It also supports thinking and problem-solving, developing and maintaining the relationships.

Item 8 "I believe teachers should teach request speech act when learners attain a specific level of language ability" was accepted by most EFL instructors and $83.3 \%$ agreed, though $16.7 \%$ disagreed. The result is in line with the interview part:

For example, teacher 18 from NB: I personally think that the level of learners is important too, I mean I start indirect teaching in advanced classes. Due to their language proficiency level, learners can easily deal with indirect way of teaching strategies.

Regarding item 9 "I teach explicit performatives of request first" all contributors (100\%) agreed with this perception. The Result is in line with the interview findings. $80 \%$ of the teachers considered direct strategy of instruction in their teaching.

For example, teacher 8 from NB: Direct teaching is effective, because it seems to be easier, understandable and without ambiguity for the learners with a low level of English knowledge. They don't need to think about other meanings of the utterance or actually to go beyond the normal meaning of the sentence.

Considering item 10 "I think conventionally indirect strategies challenge learners for learning request" the contributors were not agreed. Most of the instructors $66.7 \%$ were impartial, whereas $16.7 \%$ disagreed and another $16.7 \%$ agreed with that statement. The result supports the interview part:

For example, teacher 9 from NB: Lower proficiency learners have problems in the use of this strategy whereas expert learners overused the conventional indirect strategy form.

Concerning item 11 "I believe learning English means learning speech acts specifically request" half of the contributors agreed and half of them strongly agreed. The result supports the interview part: 
For example, teacher 6 from NB:One of the important areas of language is that of communicative speech acts that convey the willed language functions, so learning speech acts somehow means learning English.

Concerning item 12 "I think the knowledge of how to use apology speech act is necessary for EFL learners", all contributors approved or strongly agreed with it. The result is in line with the interview part:

For example, teacher 10 from NB: The improper use of speech act may lead in misinterpretation between speakers. Learners may have varied clarifications of a declaration. This is due to a failure to use speech acts in certain circumstances.

Most of the instructors $66.7 \%$ agreed with item 13 'I believe learners' consciousness raising of getting information on culture and suitable language practice is more beneficial for learning apology speech act", while $33.3 \%$ disagreed with this idea. The result is in line with the findings of interview:

For example, teacher 26 from NB: Building language awareness, in my opinion, helps learners in integrating what they've learned with new information.It also aids in problem-solving and critical thinking, as well as the formation and maintenance of relationships.

Concerning Item 14 "I believe teachers should teach apology speech act when learners attain a specific level of language ability" was accepted by most EFL instructors and $83.3 \%$ agreed, though $16.7 \%$ disagreed. The result is in line with the result of interview part:

For example, teacher 16 from NB: The level of learners is very important. Based on their language proficiency level the way of teaching can be changed. I mean indirect teaching can be used for advanced learners.

All EFL instructors agreed with item 15 "I stress on both acknowledgment of responsibility and offer of repair strategies through explicit teaching". The result supports the findings of the interview. Most candidates $66.7 \%$ considered responsibility tactic and offer of repair useful in explicit teaching of apology.

For example, teacher 27 from NB: I believe it's necessary for learners to know how to acknowledge their fault and try to compensate it.

The majority of the EFL instructors; $83.3 \%$ agreed with the item 16 "I believe that it's necessary for EFL learners to learn all apology strategies", while $16.7 \%$ disagreed with this idea. The result is in line with the interview part. $75 \%$ of teachers considered all apology strategies in their classes.

For example, teacher 14 from NB: I believe that learning apology strategies is necessary for EFL learners. Because of dissimilarities associated to the learners' mother tongue, and their culture. 
Concerning item 17 "I believe learning English means learning speech acts specifically apology" half of the contributors agreed and half of them strongly agreed. The result supports the interview part:

For example, teacher 29 from NB: One of the important aspects of language is speech act which is communicative. By learning apology speech act, learners can simply make up what they've done wrongly.

Concerning item 18 "I think the knowledge of how to use invitation speech act is necessary for EFL learners", all contributors approved or strongly agreed with it. The result is in line with the interview part:

For example, teacher 15 from NB: The appropriate use of speech act may result in better communication between interlocutors. Learners must have the knowledge of using speech acts in a specific situation.

Most of the instructors $66.7 \%$ agreed with item 19 'I believe learners' consciousness raising of getting information on culture and suitable language practice is more beneficial for learning invitation speech acts", while $33.3 \%$ disagreed with this idea. The result is in line with the findings of interview:

For example, teacher 17 from NB: I think improving language awareness helps learners to understand the new information. Knowledge of culture and appropriate use of language are two indispensable parts of language that affect learning speech acts.

Item 20 "I believe teachers should teach invitation speech act when learners attain a specific level of language ability" was accepted by most EFL instructors and $83.3 \%$ agreed, though $16.7 \%$ disagreed. The result is in line with the result of interview part:

For example, teacher 13 from NB: I think the level of learners is an important factor in learning speech acts, I mean intermediate and advanced learners can deal with the way of teaching easily.

When responding item 21 "I have had difficulties when teaching learners invitation speech act" most EFL instructors, $66.7 \%$ disagreed; while, $33.3 \%$ agreed with that notion. The result is in line with the interview part:

For example, teacher 28 from NB:The inviter's main purpose for invitation is implied. Therefore, learner may be confused. But my learners sometimes can understand the inviter's pretense.

Regarding item 22 "using genuine invitation is preferred by EFL learners." most of the instructors $83.3 \%$ agreed though $16.7 \%$ disagreed. The result supports the interview part:

For example, teacher 25 from NB: Learners prefer to use genuine invitation because it is unambiguous and contains reference to time and mention of place or activity.

Concerning item 23 "I think learning English means learning speech acts specifically invitation" $50 \%$ of the contributors agreed, whereas $50 \%$ disagreed. The result is in line with the interview part: 
For example, teacher 15 from NB: Teaching speech acts in classes can assist students to expand their speech acts performance and their communications with native speakers.

\section{Methods and Techniques used in Classes}

This section shows the findings from the questionnaire data concerning methods and techniques used by teachers in their classrooms.

Majority of the EFL teachers (66.66\%) preferred to use general pragmatic knowledge while teaching request, apology, and invitation. Result of item 1 (use of general pragmatic knowledge) is in line with item 4 of the observation. For example, metalanguage style was used for teaching offer of repair in apology speech act by Pro 3 from NB.

Most of the teachers (83.33\%) stated that they prefer to use pair work when they teach the intended speech acts. The result of item 4 (use of pair work) is in line with item 1 of the observation. For example, Pro 5 from NB used pair work while teaching genuine and invitations.

Awareness raising activities (item 6 ) are used by $83.33 \%$ of the teachers. The result is in line with item 2 of the observation. For example, Pro1 from NB used awareness raising activities when he taught direct and indirect requests.

\section{Results of qualitative stage}

Communicative Orientation of Language Teaching (COLT) observation scheme consisted of different components and adapted by the researchers was used in this phase of the study. From among these components the researchers have chosen 6 methods and techniques concerning form-focused instruction of speech acts.

Regarding the second item, Table 4.11, the majority of the teachers (66.7\%) used awareness raising activities and another $100 \%$ teachers used group discussion activities. (50 \%) used pair work in their classes. Also, $83.33 \%$ of the teachers applied metalanguage style and cultural knowledge whereas only 16.66 of the teachers used general pragmatic knowledge for teaching direct strategy of request.

Results of item 7 of the questionnaire supports item 2 of the observation scheme, which investigates 'the effect of awareness raising activities on teaching request", and instructional practices of $66.67 \%$ of the observed teachers support the results of this part; as an example Prof 1 from NB explained different strategies used for apology for 30 minutes. Then the brief situation was given to the learners and asked them to respond. She mentioned that relative status of their participants, the degree of familiarity between them and the seriousness of the offence must be considered.

Results of item 28 of the questionnaire supports item 3 of the observation scheme, which investigates 'the use of group discussion activities through explicit strategy of teaching request", and instructional 
practices of $100 \%$ of the observed teachers support the result of this part, through which learners' confidence was increased and they could generate more ideas about the topics.

Also, item 6 of the questionnaire related to the method and techniques used in the classes, supports item 2 of the observation scheme, which is related to the use of pair work and instructional practices of 83.33 $\%$ of the observed teachers which support the results of this part.

In line with the results of the observation, the majority (83.7\%) of interviewees believed in using pair work as a useful way, through which learners can exchange information with each other and learn better.

Prof 2 from NB emphasized pair work and its advantages. Prof 2 believes that "pair work can be an effective method, through which learners have opportunity to speak about an idea, share ideas and develop their understanding, enable learners to learn from each other, and give learners a degree of privacy and allow them to try ideas in a less public forum".

The results of observation and interview regarding using awareness-raising instructional tasks are in line with the findings of Tajeddin, Z., \& Hosseinpur, R. (2014), Zangoei, Esmaeel Nourmohammadi, and Derakhshan (2014) who suggest that awareness-raising instructional tasks could be utilized in raising learners' socio-pragmatic awareness (Tajeddin \& Hosseinpur, 2014; Zangoei \& Derakhshan, 2014).

Regarding the second item, Table 4.12 , the majority of the teachers $(83.33 \%)$ used awareness raising activities for teaching invitation, and another $100 \%$ teachers used group discussion activities. Most of the teachers $(66.67 \%)$ applied first cultural knowledge and then metalanguage style for teaching genuine invitation.

Results of item 28 of the questionnaire supports item 7 of the observation scheme, which focuses on group discussion through explicit strategy of teaching invitation. Also the majority of instructors $(100 \%)$ believed in using group discussion. They believed that through using group discussion, learners could know their mistakes and weaknesses.

Also, results of item 19 of the questionnaire supports item 6 of the observation scheme, which investigates 'the effect of awareness raising activities for teaching invitation", and instructional practices of $83.33 \%$ of the observed teachers support results of this part; as an example Prof 3 from NB explained both genuine invitations for almost 45 minutes. He discussed about the different features used in genuine invitation.

The result of the observation and the interview regarding using form-focused instruction are in line with Al-Shammar, Al-Sharoufi, and Yawkey (2008), Farahian, Rezaee, and Gholami (2012), and Trang Thị Đoan Đặng and Hương Thu Nguyễn (2013) who emphasized direct instruction in improving non-native learners achievement in English learning (Al-Shammar, Al-Sharoufi, \& Yawke, 2008; Đặng \& Nguyễn, 2013; Farahian, Rezaee, \& Gholami, 2012). Also, it is in line with Taguchi (2015) who believes that instruction on pragmatics is effective and that explicit teaching seems more beneficial than implicit teaching (Taguchi, 2015). 
Also Results of items 24 and 25 of the questionnaire related to the method and techniques support item 8 of the observation scheme, which investigates 'the effect of metalanguage style and cultural knowledge for teaching pragmatics", and instructional practices of $66.67 \% \%$ of the observed teachers support the results of this part.

In line with the results of the observation, the majority (66.7\%) of interviewees believed in using awareness raising tasks in teaching invitation, which leads to the learners' awareness-raising in sociocultural and sociolinguistic differences.

Regarding the first item, Table 4.13, all teachers (100\%) used pair work through explicit strategy of teaching acknowledgment of responsibility. Also, another $100 \%$ of the teachers used group discussion activities. The majority of teachers, $66.67 \%$, focused on the statement of the situation and explanation strategies through awareness raising activities. In addition, $66.67 \%$ of the teachers used metalanguage style for teaching apology strategies whereas $33.33 \%$ of the teachers applied general pragmatic.

Results of item 15 of the questionnaire supports item 9 of the observation scheme, which investigates 'the influence of teaching acknowledgment of responsibility explicitly", and instructional practices of $100 \%$ of the observed teachers support results of this part; as an example Prof 4 from NB explained acknowledgment of responsibility explicitly for 30 minutes.

Results of item 28 of the questionnaire supports item 11 of the observation scheme, which focuses on group discussion through explicit strategy of teaching apology. Also the majority of instructors $(100 \%)$ believed in using group discussion.

In line with the results of the observation, the majority (83.33\%) of interviewees believed in using group discussion through explicit strategy of teaching apology. They believed that group discussion helped learners more and it increased their understanding of the subject.

Also the results of item 29 of the questionnaire related to method and technique supports item 10 of the observation scheme, which investigates "the impact of using awareness raising activities", and instructional practices of $66.67 \%$ of the observed teachers.

In line with the results of the observation, the majority (66.7\%) of the interviewees believed in using explicit strategy in teaching acknowledgment of responsibility, which leads to the better understanding of the apology speech act.

\section{Discussion}

This study sought to investigate teachers' perceptions and practices towards form-focused instruction of speech acts in Iranian context. Concerning the quantitative part, the outcomes of the questionnaire showed that for teaching the speech acts mainly pragmatic knowledge was applied in academic setting. All teachers agreed with the necessity of teaching and using pragmatic knowledge specifically speech acts. The findings also support the previous studies which have highlighted a balance between pragmatic 
and grammatical skills as necessary factor even for learners with advanced grammatical competence who cannot practice the target language properly (Bardovi-Harlig \& Dornyei, 1998; Rose, 2009; Xu, Case, \& Wang, 2009; Yuan, 2012). Results of the investigation supports Alcon-Soler's (2015) and Taguchi's, (2015) studies which have highlighted the impact of pragmatic instruction in academic setting (AlconSoler, 2015; Taguchi, 2015).

The majority of the teachers focused on the raising learners' awareness on culture and appropriate language use. Learners attain better if they understand the position of applying language properly. The effects of pragmatic instruction were also affirmed by the findings of previous studies (Halenko \& Jones, 2011; Narita, 2012; Rezvani, Eslami-Rasekh, \& Vahid Dastjerdi, 2014). Narita (2012) concluded that through the pragmatic consciousness raising activities, learners became aware of critical differences between L1 and L2, and enhanced their L2 pragmatic competence successfully (Narita, 2012). He mentioned that the pragmatic consciousness-raising activity is effective for L2 pragmatics acquisition. And the learners showed interest in the pragmatic consciousness-raising activities with metalinguistic discussion.

The majority of teachers emphasized speech acts should be taught to the learners when they gain a certain level of language proficiency. Results of the investigation support the previous study by Taguchi (2013). The findings of the study showed that both language proficiency and target language exposure could contribute to the development of pragmatic competence (Taguchi, 2013). But the result of the present study is not in line with Rafieyan (2018). He didn't find any correspondence between the degree of language contact and the improvement of pragmatic competence (Rafieyan, 2018).

The findings of this study revealed that there is no worldwide method or technique for teaching pragmatics and most of the teachers made use of explicit approaches with the integration of different techniques such as pair work, group discussion, awareness raising, providing learners with general pragmatic knowledge, meta-language styles and cultural knowledge. These were the most repeated methods and techniques used by the instructors for explicit teaching of speech acts. The findings of the previous studies support the results of the present study. Abdullah (2016) conducted his research on the improvement of speaking skills through group work. The result of his research indicated that the learners responded very well towards the implementation of the group work activities (Abdullah, 2016). Mulya (2016) conducted her research by applying pair work technique. The result showed that the pair work technique was an effective technique for the learners in improving their speaking performances (Mulya, 2016).

The result of the interview and the observation revealed that teachers acknowledged the essential role of teaching pragmatic information and supposed explicit instruction of strategy is more effective. Since, this technique seems to be easier, understandable and without ambiguity for the learners. Results of this subsection are in line with (Al-Shammar et al., 2008; Đặng \& Nguyễn, 2013; Farahian et al., 2012). Which have highlighted the efficiency of direct and explicit teaching in improving non-native students' achievement in English learning. It's worth noting that the approach used for teaching pragmatics was teacher-centered, 
meaning that teachers directly clarified pragmatics to learners. To be specific, the study showed that more than $90 \%$ of the teachers focused on teaching pragmatic knowledge by explanation. Results of this sub-section are in line with Norris and Ortega (2000), simulation activities follow the explicit instruction includes description, explanation, and discussion of pragmatic features (Norris \& Ortega, 2000).

This study revealed that more than $80 \%$ of teachers focused on raising learners' awareness to gain information on how to use language appropriately. Raising language learners' pragmatic understanding will assist them in gaining knowledge about pragmatic features of language (Niezgoda \& Rover, 2001). One of the key objectives of teaching pragmatics, Bardovi-Harlig and Mahan-Taylor (2003a), is to increase learners' pragmatic understanding (Bardovi-Harlig \& Mahan-Taylor, 2003a).

The findings also revealed that most of the teachers used group discussion which helped the learners enhance their self-confidence and understanding of the subject, and pair work activities which helped the learners exchange information with each other and learn better which support the above mentioned studies by the other researchers.

\section{Conclusions}

The findings obtained from the questionnaire, the observation scheme and the semi-structured interview delivered rich and informative data about the needs of the teachers and their instructional perceptions and practices concerning pragmatic knowledge development in academic setting. The collected data were examined quantitatively and qualitatively. The results of the first question concerning the perceptions of the teachers towards form-focused instruction of speech acts showed that Iranian EFL learners were attentive in explicit education concerning the pragmatic structure of speech acts. Though, the present investigation did not focus on the order of attaining tactics of speech acts, it revealed that explicit meta-pragmatic education had significant effect on the understanding processes of speech acts of the learners. These findings support several studies (Arabmofrad et al., 2019; Farahian et al., 2012; Ifantidou, 2013; Ji, 2007). which have highlighted the dominant role of direct and explicit meta-pragmatic instruction. Considering the findings of the first question, it can be concluded that form-focused instruction of speech acts is mostly focused by Iranian EFL instructors. Most of them agreed with the use of explicit strategies for instructing request, apology and invitation speech acts rather than implicit strategies.

The second research question concerning the practices of teachers towards form-focused instruction of speech acts showed that explicit and direct instruction of speech acts was mostly used by the teachers and it was more beneficial to the realization of request, apology and invitation speech acts. The majority of teachers believed that they used awareness-raising events, pair work and group discussion activities, enhanced general pragmatic knowledge and cultural knowledge and used meta-language styles in their classes to teach English language. The findings are in line with some studies (Bakhshayesh \& Jafari, 2018; Rahimi Domakani \& Hashemian, 2014; Tajeddin \& Hosseinpur, 2014) which have suggested awareness-raising for instructional tasks specifically raising learners' socio-pragmatic awareness and 
promoting their interlanguage pragmatics. Also, the findings are in line with other studies such as Abdullah's (2016) investigation on the improvement of speaking skills through group discussion and Mulya's (2016) study on applying pair work technique to improve speaking performances (Abdullah, 2016; Mulya, 2016).

In conclusion, the present study revealed that form-focused instruction of pragmatics can contribute to the development of learners' knowledge. The application of various tasks and activities that appeal to different learner styles and that require learners' use of the speech acts may have contributed to the learners' improvement. In order to improve learners' pragmatic ability, the instructors should provide language learners with rich and contextually appropriate input as an essential condition. To this aim, the learners have to be exposed to contextualized and appropriate linguistic data. The outcomes of the current study suggest a new insight towards the content of syllabi and textbooks. It assists syllabus designers and material developers particularly in EFL context. This investigation needs repetition and expansion; since, it has some limitations such as researchers merely focused on learners above intermediate level, and only request, apology, and invitation speech acts were investigated. Researchers recommend pragmatic teaching in the foreign language classes at all stages and for all of the different speech acts.

\section{Abbreviations}

EFL: English as a Foreign Language

IAU: Islamic Azad University

COLT: Communicative Orientation of Language Teaching

M: Mean

SD: Standard Deviation

\section{Declarations}

\section{Acknowledgments}

The authors of the current study would like to express their deepest gratitude to the Islamic Azad University of Varamin because of financial support for conducting the current investigation. Additionally, the authors want to expand their thankfulness to the students of Islamic Azad University for their kind participation in the data collection procedure.

\section{Authors' contributions}

In the current investigation, first author MA conducted the research by applying the sequential mixed methods design. She analyzed the data using the SPSS software and reported the data through this 
paper. N.GH read and revised the paper several time and provided the researcher with her invaluable comments. RR read and revised the paper several time and provided the researcher with his invaluable comments. The authors read and approved the final script.

\section{Authors' information}

Melahat Amir Jahansouz Shahi is a Ph.D. candidate of teaching English as a foreign language (TEFL) at Islamic Azad University, Varamin, Pishva Branch, Tehran, Iran. Her current research interest is TEFL.

Email: Jahansouz_m@yahoo.com

Neda Gharagozloo (corresponding author) is an assistant professor of TEFL at English Language Department of Islamic Azad University, Varamin, Pishva Branch. Her current research interests cover applied linguistics: methodology, assessment, linguistics (cognitive linguistics). Email:

N.gh@iauvaramin.ac.ir

Reza Raissi is an assistant professor of TEFL at English language Department at Islamic Azad University, Varamin, Pishva Branch. His current research interests cover teaching English as a foreign language, learning strategies, methodology and language assessment. Email: rezaraissi99@gmail.com

\section{Funding}

Current investigation has been supported financially by Islamic Azad University of Varamin, Pishva campus during data collection.

\section{Availability of data and materials}

The data which have been reported in the current investigation, have been collected from Islamic Azad University, Tehran Iran. To access the data, you may contact the corresponding author to request the data.

\section{Competing interests}

The writers assert that they have no competing interests.

\section{References}

1. Abdullah. (2016). Group Work Activities For Improving Speaking Skill. English Education Journal (EEJ), 7(3), 393.

2. Al-Shammar, Z., Al-Sharoufi, H., \& Yawke, T. (2008). The Effectiveness of Direct Instruction in Teaching English in Elementary Public Education Schools in Kuwait: A Research Case Study. Retrieved from https://www.researchgate.net/publication/273527436

3. Alco'n, E., \& Pitarch, J. G. (2010). The effect of instruction on learners' pragmatic awareness: A focus on refusals. International Journal of English Studies, 10(1), 65-80. 
4. Alcon-Soler, E. (2015). Pragmatic learning and study abroad: Effects of instruction and length of stay. System, 48, 62-74.

5. Alcón Soler, E. (2002). Relationship between teacher-led versus learners' interaction and the development of pragmatics in the EFL classroom. International Journal of Educational Research, 37(3), 359-377.

6. Alerwi, A. A., \& Alzahrani, A. (2020). Using sitcoms to improve the Acquisition of Speech Acts by EFL students: Focusing on request, refusal, apology, and compliment response. Journal of Applied Linguistics and Language Research, 7(1), 63-79.

7. Alinezhad, A. (2015). The Significance of Pragmatics in English Language Teaching. 'ELT Voices India' International Journal for Teachers of English., 5(1), 19-24.

8. Ansarin, A. A., \& Mohamadi, Z. (2013). Language engagement at the level of syntax: Assessing Metatalk and task types in SLA. International Journal of Applied Linguistics and English Literature, 2(4), 142-154.

9. Arabmofrad, A., Derakhshan, A., \& Atefinejad, M. (2019). An Interplay Between Iranian EFL Learners' Specific and General Interlanguage Pragmatic Motivation and Their Meta-Pragmatic Awareness. Iranian Journal of English for Academic Purposes.

10. Aufa, F. (2013). The Assessment Tool of L2 Learners' Pragmatic Competence: Written Discourse Completion Test (WDCT). International Proceedings of Economics Development \& Research, 68.

11. Azarmi, A., \& Behnam, B. (2012). The Pragmatic Knowledge of Iranian EFL Learners in Using Face Keeping Strategies in Reaction to Complaints at Two Different Levels. Retrieved from http://dx.doi.org/10.5539/elt.v5n2p78

12. Bakhshayesh, S., \& Jafari, K. (2018). The effects of input enhancement and explicit instruction on developing Iranian lower-intermediate EFL learners' explicit knowledge of passive voice. Asian-Pacific journal of Second and Foreign Language Education., 18.

13. Bardovi-Harlig, K. (2001). Evaluating the empirical evidence: Grounds for instruction in pragmatics, (In K. R. Rose \& G. Kasper (Eds.), Pragmatics in language teaching ed.). New York, NY: Cambridge University Press.

14. Bardovi-Harlig, K., \& Dornyei, Z. (1998). Do language learners recognize pragmatic violations? Pragmatic versus grammatical awareness in instructed L2 learning. TESOL Quarterly, 32(2), 233-262.

15. Bardovi-Harlig, K., \& Mahan-Taylor, R. (2003a). Introduction (In K. Bardovi-Harlig \& R.Mahan-Taylor (Eds.) Teaching pragmatics ed.). Washington, DC: United States Department of State.

16. Blum-Kulka, S., \& Olshtain, E. (1984). Requests and apologies: a cross-cultural study of speech act realization pattern(CCSARP). Applied linguistics 5(3), 196-213.

17. Braun, V., \& Clarke, V. (2006). Using thematic analysis in psychology. Qualitative Research in Psychology, 3, 77-101. doi:doi:10.1191/1478088706qp063oa

18. Brown, P., \& Levinson, S. C. (1978). Universals in language usage: politeness phenomena. (In E. Goody (Ed.), Questions and politeness: Strategies in social interaction ed.). Cambridge: Cambridge University Press. 
19. Crandall, E., \& Basturkmen, H. (2004). Evaluating pragmatics-focused materials. ELT Journal, 58(1), 38-49.

20. Đặng, T. T. Đ., \& Nguyễn, H. T. (2013). Direct versus Indirect Explicit Methods of Enhancing EFL Students' English Grammatical Competence: A Concept Checking-based Consciousness-raising Tasks Model. The Journal of English Language Teaching, 6(1).

21. DeCapua, A., \& Dunham, J. F. (2007). The pragmatics of advice giving: Cross-cultural perspectives. Intercultural Pragmatics, 4(3), 319-342.

22. Dole, J. A. (2000). Explicit and implicit instruction in comprehension. Reading for meaning: Fostering comprehension in the middle grades, 52-69.

23. Dornyei, Z., \& Taguchi, T. (2010). Questionnaires in second language research: Construction, administration, and processing (2nd ed.). Routledge.

24. Ezzy, D. (2002). Qualitative analysis: Practice and innovation. Sydney, NSW: Psychology Press.

25. Farahian, M., Rezaee, M., \& Gholami, A. (2012). Does direct instruction develop pragmatic competence? Teaching refusal to EFL learners of English. Journal of Language Teaching and Research, 3(4), 814-821.

26. Farshi, S., \& Baghbani, S. (2015). The effects of implicit and explicit focus on form on oral accuracy of EFL learners. Theory and Practice in Language Studies, 5(2), 292-297.

27. Fordyce, K. (2014). The differential effects of explicit and implicit instruction on EFL learners' use of epistemic stance. Applied Linguistics, 35(1), 6-28.

28. Goffman, E. (1971). Remedial interchanges. In Relations in public: Microstudies of the public order. New York: Harper.

29. Halenko, N., \& Jones, C. (2011). Teaching pragmatic awareness of spoken requests to Chinese EAP learners in the UK: Is explicit instruction effective? System, 39(2), 240-250.

30. Hinkel, E. (1997). Appropriateness of advice: DCT and multiple choice data 1. Applied Linguistics, $18(1), 1-26$.

31. Ifantidou, E. (2013). Pragmatic competence and explicit instruction. Journal of Pragmatics, 59, 93116.

32. Ji, P. (2007). Pragmatics and pedagogy: An examination of college english training in China (unpublished doctoral thesis), University of Sydney, Australia.

33. Kachru, B. B. (1992a). Models for non-native Englishes. In B. B. Kachru (Ed.), The other tongue: English across cultures (2nd ed.) ed.). Urbana and Chicago: University of Illinois Press.

34. Kasper, G. (2001). Classroom research on interlanguage pragmatics. (In K.R. Rose \& G. Kasper (Eds.), Pragmatics in Language Teaching ed.). Cambridge: Cambridge University Press.

35. Kondo, S. (2008). Effects on pragmatic development through awareness-raising instruction: Refusals by Japanese EFL learners. Investigating pragmatics in foreign language learning, teaching and testing, 153-117. 
36. Krisnawati, K. (2011). Pragmatic competence in the spoken English classroom. Indonesian Journal of Applied Linguistics, 1(1), 100-110.

37. Longman. Choraih, M., Loutfi, A., \& Mansoor, A. (2016). The Importance of Pragmatic Competence in the EFL Curriculum: Application and Implications. ASELS Annual Conference Proceedings.

38. Martínez-Flor, A., \& Usó-Juan, E. (2010). The teaching of speech acts in second and foreign language instructional contexts. Pragmatics Across Languages and Cultures, 7, 423.

39. Martínez Flor, A. (2005). A theoretical review of the speech act of suggesting: Towards a taxonomy for its use in FLT. Revista Alicantina de Estudios Ingleses, 18, 167-187.

40. Mulya, R. (2016). Teaching Speaking By Applying Pair Work Technique. Aceh. English Education Journal (EEJ), 5(1), 389.

41. Narita, R. (2012). The effects of pragmatic consciousness-raising activity on the development of pragmatic awareness and use of hearsay evidential markers for learners of Japanese as a foreign language. Journal of Pragmatics, 44, 1-29.

42. Niezgoda, K., \& Rover, C. (2001). Pragmatic and grammatical awareness: A function of the learning environment? ( In K. R. Rose \& G. Kasper (Eds.), Pragmatics in language teaching ed.). Cambridge: Cambridge University Press.

43. Norris, J., \& Ortega, L. (2000). Effectiveness of L2 instruction: A research synthesis and quantitative meta-analysis. Language Learning, 50(3), 417-528.

44. Nurani, N. P. (2015). A pragmatic analysis of classroom speech acts in the English teaching and learning process at SMA N 1 Purworejo (A Case Study). (Unpublished Thesis). Yogyakarta State University, Indonesia,

45. Olshtain, E., \& Cohen, A. D. (1990). The learning of complex speech act behavior. TESL Canada Journal, 7(2), 45-65.

46. Patton, M. (2001). Qualitative evaluation and research methods. Beverly Hills, CA: Sage.

47. Pishghadam, R., \& Sharafaddini, M. (2011). Delving into speech act of suggestion: A case of Iranian EFL learners. International Journal of Business and Social Science, 2, 152-160.

48. Rafieyan, V. (2018). Knowledge of Formulaic Sequences as a Predictor of Language Proficiency. International Journal of Applied Linguistics \& English Literature, 7(2), 64-69. Retrieved from https://doi.org/10.7575/aiac.ijalel.v.7n.2p.64

49. Rahimi Domakani, M., \& Hashemian, M. (2014). Pragmatic Awareness of the Request Speech Act in English as an Additional Language: Monolinguals or Bilinguals? : publication at: https://www.researchgate.net/publication/339596029.

50. Rajabi, S., \& Farahian, M. (2013). The effects of pragmatic instruction on EFL learners' awareness of suggestions. Modern Journal of Language Teaching Methods, 3(3), 28-38.

51. Rajabia, S., Azizifara, A., \& Gowhary, H. (2015). The effect of explicit instruction on pragmatic competence development; teaching requests to EFL learners of English. Procedia-Social and Behavioral Sciences, 199(3), 231-239. 
52. Rezvani, E., Eslami-Rasekh, A., \& Vahid Dastjerdi, H. (2014). Investigating the effects of explicit and implicit instruction on Iranian EFL learners' pragmatic development: Speech acts of requests and suggestions in focus. International Journal of Research Studies in Language Teaching, 3(7), 3-14. doi:10.5861/ijirsll.2014.799

53. Rose, K. R. (2009). Interlanguage pragmatic development in Hong Kong, phase 2. Journal of Pragmatics, 41(11), 2345-2364.

54. Salemi, A., Rabiee, M., \& Ketabi, S. (2012). The Effects of Explicit/Implicit Instruction and Feedback

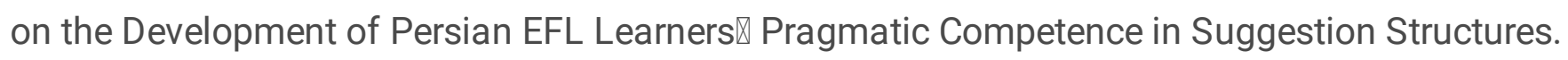
Journal of Language Teaching and Research, 3(1), 188-199.

55. Schmidt, R. (1990). The role of consciousness in second language learning. Applied Linguistics, 11, 17-46.

56. Schmidt, R. (1993). Consciousness, learning and interlanguage pragmatics (In G. Kasper \& S. BlumKulka (Eds.), Interlanguage pragmatics ed.): New York: Oxford University Press.

57. Searle, J. R. (1975). Indirect Speech Acts (in Peter Cole and Jerry L. Morgan (eds), Syntax and Semantics ed. Vol. 3): Speech Acts, Academic Press.

58. Spada, N., \& Fröhlich, M. (1995). The communicative orientation of language teaching observation scheme (COLT). Sydney, Australia: MacMillan.

59. Taguchi, N. (2013). Production of Routines in L2 English: Effect of Proficiency and Study-Abroad Experience. System, 41(1), 109-121. Retrieved from https://doi.org/10.1016/j.system.2013.01.00

60. Taguchi, N. (2015). Instructed pragmatics at a glance: where instructional studies were, are, and should be going. Language Teaching 48(1), 1-50.

61. Tajeddin, Z., \& Hosseinpur, R. (2014). The Impact of Deductive, Inductive, and L1-Based Consciousness-Raising Tasks on EFL Learners' Acquisition of the Request Speech Act. The Journal of Teaching Language Skills (JTLS), 73-92.

62. Wilson, M. (2014). The British environmental movement: The development of an environmental consciousness and environmental activism. (Unpublished doctoral dissertation). University of Northumbria,

63. Xu, W., Case, R. E., \& Wang, Y. (2009). Pragmatic and grammatical competence, length of residence, and overall L2 proficiency. System, 37(2), 205-216.

64. Yuan, Y. (2012). Pragmatics, perceptions and strategies in Chinese College English learning. (Unpublished doctoral thesis). Queensland University of Technology, Australia.,

65. Zangoei, A., \& Derakhshan, A. (2014). Iranian EFL learners' ILP comprehension and their language learning preferences: The effect of consciousness- raising instruction. International Journal of Language Learning and Applied Linguistics World (IJLLALW), 5(2), 211-232.

\section{Tables}

Table 4.1 
Teachers' questionnaire: Items related to Perceptions towards Teaching Pragmatics (Ji,2007 \& Kachru,1992a)

\begin{tabular}{|ll|}
\hline Components & Questionnaire items \\
\hline Request & $6,7,8,9,10,11$ \\
\hline Apology & $12,13,14,15,16,17$ \\
\hline Invitation & $18,19,20,21,22,23$ \\
\hline
\end{tabular}

Table 4.2

Teachers' questionnaire: Items related to the Methods and Techniques applied in the class(Ji,2007 \& Kachru,1992a))

\begin{tabular}{|ll|}
\hline Components & Questionnaire items \\
\hline Request & $24,25,26,27,28,29$ \\
\hline Apology & $24,25,26,27,28,29$ \\
\hline Invitation & $24,25,26,27,28,29$ \\
\hline
\end{tabular}

Table 4.3

Ranking of speech acts constructs based on Mean Index of the Teachers' Questionaire

\begin{tabular}{|lll|}
\hline Constructs & Mean & SD \\
\hline Request & 4.12 & 0.45 \\
\hline Apology & 3.97 & 0.56 \\
\hline Invitation & 3.86 & 0.63 \\
\hline
\end{tabular}

$\mathrm{SD}=$ Standard Deviation 


\begin{tabular}{|c|c|c|c|c|}
\hline \multicolumn{5}{|c|}{$\begin{array}{l}\text { Table } 4.4 \\
\text { Demographic Information of Instructors }\end{array}$} \\
\hline Items & \multicolumn{2}{|l|}{ Male } & \multicolumn{2}{|l|}{ Female } \\
\hline 1-Gender & 10 & & 20 & \\
\hline \multirow[t]{3}{*}{ 2- Teaching Experience } & - & & & \\
\hline & $\underline{0-5}$ & & $\underline{6-10}$ & $\underline{11-15}$ \\
\hline & 4 & & 20 & 6 \\
\hline \multicolumn{5}{|l|}{ 3- Degree } \\
\hline & & $\underline{\mathrm{PhD}}$ & $\underline{\text { PhD Candidate }}$ & \\
\hline & & 16 & 14 & \\
\hline \multicolumn{5}{|l|}{ 4- Major } \\
\hline & \multicolumn{2}{|r|}{$\underline{\text { TEFL }}$} & Translation & \\
\hline & 25 & 5 & & \\
\hline \multicolumn{5}{|l|}{ 5- Overseas learning } \\
\hline & No & & No & \\
\hline
\end{tabular}

Table 4.5

Teachers' Perceptions towards Teaching Pragmatics of Request (Ji,2007 \& Kachru,1992a) 


\begin{tabular}{|c|c|c|c|c|c|c|c|c|}
\hline Questionnaire items & $\begin{array}{l}\text { Strongly } \\
\text { Disagree }\end{array}$ & Disagree & Neutral & Agree & $\begin{array}{l}\text { Strongly } \\
\text { Agree }\end{array}$ & $\mathbf{N}$ & Mean & SD \\
\hline \multirow{2}{*}{$\begin{array}{l}6-\text { I think the } \\
\text { knowledge of how to } \\
\text { use request is } \\
\text { necessary for EFL } \\
\text { learners }\end{array}$} & \multirow[t]{2}{*}{-} & \multirow[t]{2}{*}{-} & \multirow[t]{2}{*}{-} & 15 & 15 & \multirow[t]{2}{*}{30} & \multirow[t]{2}{*}{4.5} & \multirow[t]{2}{*}{0.50} \\
\hline & & & & $50 \%$ & $50 \%$ & & & \\
\hline \multirow{2}{*}{$\begin{array}{l}\text { 7- I think learners' } \\
\text { consciousness raising } \\
\text { of gaining } \\
\text { information on culture } \\
\text { and suitable language } \\
\text { use is more beneficial } \\
\text { for learning request }\end{array}$} & \multirow[t]{2}{*}{-} & 10 & \multirow[t]{2}{*}{-} & 10 & 10 & \multirow[t]{2}{*}{30} & \multirow[t]{2}{*}{3.66} & \multirow[t]{2}{*}{1.28} \\
\hline & & $33.3 \%$ & & $33.3 \%$ & $33.3 \%$ & & & \\
\hline \multirow{2}{*}{$\begin{array}{l}\text { 8- I believe instructors } \\
\text { should teach request } \\
\text { speech acts when } \\
\text { learners attain a } \\
\text { certain level of } \\
\text { language ability }\end{array}$} & \multirow[t]{2}{*}{-} & 5 & \multirow[t]{2}{*}{-} & 13 & 12 & \multirow[t]{2}{*}{30} & \multirow[t]{2}{*}{4.06} & \multirow[t]{2}{*}{1.04} \\
\hline & & $16.7 \%$ & & $43.3 \%$ & $40 \%$ & & & \\
\hline \multirow{2}{*}{$\begin{array}{l}\text { 9- I teach explicit } \\
\text { performatives of } \\
\text { request first }\end{array}$} & \multirow[t]{2}{*}{-} & \multirow[t]{2}{*}{-} & \multirow[t]{2}{*}{-} & 15 & 15 & \multirow[t]{2}{*}{30} & \multirow[t]{2}{*}{4.5} & \multirow[t]{2}{*}{0.50} \\
\hline & & & & $50.0 \%$ & $50.0 \%$ & & & \\
\hline \multirow{2}{*}{$\begin{array}{l}\text { 10-I think } \\
\text { conventionally } \\
\text { indirect strategies } \\
\text { challenge learners for } \\
\text { learning request }\end{array}$} & \multirow[t]{2}{*}{-} & \multirow[t]{2}{*}{-} & 20 & 5 & 5 & \multirow[t]{2}{*}{30} & \multirow[t]{2}{*}{3.5} & \multirow[t]{2}{*}{0.77} \\
\hline & & & $66.7 \%$ & $16.7 \%$ & $16.7 \%$ & & & \\
\hline \multirow{2}{*}{$\begin{array}{l}11-\text { I believe learning } \\
\text { English means } \\
\text { learning speech acts } \\
\text { specifically request }\end{array}$} & \multirow[t]{2}{*}{-} & \multirow[t]{2}{*}{-} & & 15 & 15 & \multirow[t]{2}{*}{30} & \multirow[t]{2}{*}{4.5} & \multirow[t]{2}{*}{0.50} \\
\hline & & & & $50.0 \%$ & $50.0 \%$ & & & \\
\hline Total & & & & & & & 4.12 & 0.45 \\
\hline
\end{tabular}

Table 4.6

Teachers' Perceptions towards Teaching Pragmatics of Apology (Ji,2007 \& Kachru,1992a) 


\begin{tabular}{|c|c|c|c|c|c|c|c|c|}
\hline Questionnaire items & $\begin{array}{l}\text { Strongly } \\
\text { Disagree }\end{array}$ & Disagree & Neutral & Agree & $\begin{array}{l}\text { Strongly } \\
\text { Agree }\end{array}$ & $\mathbf{N}$ & Mean & SD \\
\hline \multirow{2}{*}{$\begin{array}{l}12-\text { I think the } \\
\text { knowledge of how to } \\
\text { use apology is } \\
\text { necessary for EFL } \\
\text { learners }\end{array}$} & - & - & - & 15 & 15 & 30 & 4.5 & 0.50 \\
\hline & & & & $50.0 \%$ & $50.0 \%$ & & & \\
\hline \multirow{2}{*}{$\begin{array}{l}13-\text { I think learners' } \\
\text { consciousness } \\
\text { raising of getting } \\
\text { information }\end{array}$} & - & 10 & - & 10 & 10 & 30 & 3.66 & 1.28 \\
\hline & & $33.3 \%$ & & $33.3 \%$ & $33.3 \%$ & & & \\
\hline \multicolumn{9}{|l|}{$\begin{array}{l}\text { on culture and } \\
\text { suitable language } \\
\text { practice is more } \\
\text { beneficial for } \\
\text { learning apology }\end{array}$} \\
\hline \multirow{2}{*}{$\begin{array}{l}\text { 14- I think instructors } \\
\text { should teach } \\
\text { apology speech act } \\
\text { when learners } \\
\text { achieve a certain } \\
\text { level of language } \\
\text { ability }\end{array}$} & - & 5 & - & 13 & 12 & 30 & 4.06 & 1.04 \\
\hline & & $16.7 \%$ & & $43.3 \%$ & $40 \%$ & & & \\
\hline \multirow{2}{*}{$\begin{array}{l}\text { 15- I stress on both } \\
\text { acknowledgment of } \\
\text { responsibility and } \\
\text { offer of repair } \\
\text { strategies through } \\
\text { explicit teaching }\end{array}$} & - & - & - & 30 & & 30 & 3.00 & 0.00 \\
\hline & & & & $100.0 \%$ & & & & \\
\hline \multirow{2}{*}{$\begin{array}{l}\text { 16- I believe that it's } \\
\text { necessary for EFL } \\
\text { learners to learn all } \\
\text { apology strategies }\end{array}$} & - & 5 & - & 12 & 13 & 30 & 4.10 & 1.06 \\
\hline & & $16.7 \%$ & & $40 \%$ & $43.3 \%$ & & & \\
\hline \multirow{2}{*}{$\begin{array}{l}\text { 17- I believe learning } \\
\text { English means } \\
\text { learning speech acts } \\
\text { specifically apology }\end{array}$} & - & - & - & 15 & 15 & 30 & 4.5 & 0.50 \\
\hline & & & & $50.0 \%$ & $50.0 \%$ & & & \\
\hline Total & & & & & & & 3.97 & 0.56 \\
\hline
\end{tabular}

Table 4.7

Teachers' Perceptions towards Teaching Pragmatics of Invitation (Ji,2007 \& Kachru,1992a) 


\begin{tabular}{|c|c|c|c|c|c|c|c|c|}
\hline Questionnaire items & $\begin{array}{l}\text { Strongly } \\
\text { Disagree }\end{array}$ & Disagree & Neutral & Agree & $\begin{array}{l}\text { Strongly } \\
\text { Agree }\end{array}$ & $\mathbf{N}$ & Mean & SD \\
\hline \multirow{2}{*}{$\begin{array}{l}18-\text { I think the } \\
\text { knowledge of how to } \\
\text { use invitation is } \\
\text { necessary for EFL } \\
\text { learners }\end{array}$} & \multirow[t]{2}{*}{-} & \multirow[t]{2}{*}{-} & \multirow[t]{2}{*}{-} & 15 & 15 & \multirow[t]{2}{*}{30} & \multirow[t]{2}{*}{4.50} & \multirow[t]{2}{*}{0.50} \\
\hline & & & & $50.0 \%$ & $50.0 \%$ & & & \\
\hline \multirow{2}{*}{$\begin{array}{l}\text { 19- I think learners' } \\
\text { consciousness raising } \\
\text { of getting information } \\
\text { on culture and } \\
\text { suitable language } \\
\text { practice is more } \\
\text { beneficial for learning } \\
\text { invitation }\end{array}$} & \multirow[t]{2}{*}{-} & 10 & \multirow[t]{2}{*}{-} & 10 & 10 & \multirow[t]{2}{*}{30} & \multirow[t]{2}{*}{3.66} & \multirow[t]{2}{*}{1.28} \\
\hline & & $33.3 \%$ & & $33.3 \%$ & $33.3 \%$ & & & \\
\hline \multirow{2}{*}{$\begin{array}{l}20-\text { I think teachers } \\
\text { should teach } \\
\text { invitation }\end{array}$} & \multirow[t]{3}{*}{-} & 5 & \multirow[t]{3}{*}{-} & 13 & 12 & \multirow[t]{3}{*}{30} & \multirow[t]{3}{*}{4.06} & \multirow[t]{3}{*}{1.04} \\
\hline & & $16.7 \%$ & & $43.3 \%$ & $40 \%$ & & & \\
\hline $\begin{array}{l}\text { speech act when } \\
\text { learners attain a } \\
\text { certain level of } \\
\text { language ability }\end{array}$ & & & & & & & & \\
\hline \multirow{2}{*}{$\begin{array}{l}21-\text { I have had } \\
\text { difficulties when } \\
\text { teaching learners } \\
\text { invitation speech act }\end{array}$} & \multirow[t]{2}{*}{-} & 20 & \multirow[t]{2}{*}{ - } & 5 & 5 & \multirow[t]{2}{*}{30} & \multirow[t]{2}{*}{2.83} & \multirow[t]{2}{*}{1.23} \\
\hline & & $66.7 \%$ & & $16.7 \%$ & $16.7 \%$ & & & \\
\hline \multirow{2}{*}{$\begin{array}{l}\text { 22- Using genuine } \\
\text { invitation is preferred } \\
\text { by EFL learners }\end{array}$} & \multirow[t]{2}{*}{-} & 5 & \multirow[t]{2}{*}{-} & 25 & - & \multirow[t]{2}{*}{30} & \multirow[t]{2}{*}{3.66} & \multirow[t]{2}{*}{0.75} \\
\hline & & $16.7 \%$ & & $83.3 \%$ & & & & \\
\hline \multirow{2}{*}{$\begin{array}{l}\text { 23- I believe learning } \\
\text { English means } \\
\text { learning speech acts } \\
\text { specifically invitation }\end{array}$} & \multirow[t]{2}{*}{-} & \multirow[t]{2}{*}{-} & \multirow[t]{2}{*}{-} & 15 & 15 & \multirow[t]{2}{*}{30} & 4.5 & 0.50 \\
\hline & & & & $50.0 \%$ & $50.0 \%$ & & & \\
\hline Total & & & & & & & 3.86 & 0.63 \\
\hline
\end{tabular}

Table 4.8

Methods and Techniques Used in teaching Request, Apology, And Invitation(Ji,2007 \& Kachru,1992a) 


\begin{tabular}{|c|c|c|c|c|c|c|c|c|}
\hline Items & $\begin{array}{l}\text { Very } \\
\text { much }\end{array}$ & Much & Moderate & $\begin{array}{l}\text { A } \\
\text { little }\end{array}$ & Little & $\mathbf{N}$ & Mean & SD \\
\hline \multirow{2}{*}{$\begin{array}{l}\text { 24- Providing the learners } \\
\text { with general pragmatic } \\
\text { knowledge }\end{array}$} & 20 & 10 & \multirow[t]{2}{*}{-} & \multirow[t]{2}{*}{-} & \multirow[t]{2}{*}{-} & \multirow[t]{2}{*}{30} & \multirow[t]{2}{*}{4.66} & \multirow[t]{2}{*}{0.47} \\
\hline & $66.66 \%$ & $33.34 \%$ & & & & & & \\
\hline \multirow{2}{*}{$\begin{array}{l}\text { 25-Using Meta-language } \\
\text { styles }\end{array}$} & 20 & 10 & \multirow[t]{2}{*}{ - } & \multirow[t]{2}{*}{ - } & \multirow[t]{2}{*}{-} & \multirow[t]{2}{*}{30} & \multirow[t]{2}{*}{4.66} & \multirow[t]{2}{*}{0.47} \\
\hline & $66.66 \%$ & $33.3 \%$ & & & & & & \\
\hline \multirow{2}{*}{$\begin{array}{l}\text { 26- Enhancing cultural } \\
\text { knowledge and explicit } \\
\text { language use }\end{array}$} & 25 & 5 & \multirow[t]{2}{*}{ - } & \multirow[t]{2}{*}{-} & \multirow[t]{2}{*}{-} & \multirow[t]{2}{*}{30} & \multirow[t]{2}{*}{4.83} & \multirow[t]{2}{*}{0.37} \\
\hline & $83.33 \%$ & $16.67 \%$ & & & & & & \\
\hline \multirow{2}{*}{$\begin{array}{l}27-\text { Using pair work } \\
\text { activities }\end{array}$} & 25 & \multirow[t]{2}{*}{-} & 5 & \multirow[t]{2}{*}{-} & \multirow[t]{2}{*}{-} & \multirow[t]{2}{*}{30} & \multirow[t]{2}{*}{4.50} & \multirow[t]{2}{*}{1.13} \\
\hline & $83.33 \%$ & & $16.7 \%$ & & & & & \\
\hline \multirow{2}{*}{$\begin{array}{l}28 \text { - Using group discussion } \\
\text { activities }\end{array}$} & 5 & 25 & \multirow[t]{2}{*}{ - } & \multirow[t]{2}{*}{-} & \multirow[t]{2}{*}{-} & \multirow[t]{2}{*}{30} & \multirow[t]{2}{*}{1.66} & \multirow[t]{2}{*}{1.51} \\
\hline & $16.67 \%$ & $83.33 \%$ & & & & & & \\
\hline \multirow{2}{*}{$\begin{array}{l}29 \text { - Using awareness raising } \\
\text { activities }\end{array}$} & 25 & 5 & \multirow[t]{2}{*}{-} & \multirow[t]{2}{*}{-} & - & 30 & 4.83 & 0.37 \\
\hline & $83.33 \%$ & $16.67 \%$ & & & & & & \\
\hline Total & & & & & & & 4.19 & 1.24 \\
\hline
\end{tabular}

Table 4.9

Observation scheme: Items concerning the Methods and Techniques applied in the class(Spada \& Fröhlich, 1995)

\begin{tabular}{|ll|}
\hline Components & Observation Scheme Items \\
\hline Request & $1,2,3,4$ \\
\hline Apology & $5,6,7,8$ \\
\hline Invitation & $9,10,11,12$ \\
\hline
\end{tabular}


Table 4.10

Ranking of speech acts constructs based on Mean Index of the Teachers' Observation Scheme

\begin{tabular}{|lll|}
\hline Constructs & Mean & SD \\
\hline Request & 5.08 & 0.61 \\
\hline Invitation & 4.87 & 0.16 \\
\hline Apology & 4.83 & 0.19 \\
\hline
\end{tabular}

$\mathrm{SD}=$ Standard Deviation

Table 4.11

Observation scheme regarding teaching pragmatic of request(Spada \& Fröhlich, 1995)

\begin{tabular}{|c|c|c|c|c|c|c|}
\hline Items & Never & Seldom & Moderate & Much & $\begin{array}{l}\text { Very } \\
\text { Much }\end{array}$ & $\mathbf{N}$ \\
\hline \multirow{2}{*}{$\begin{array}{l}\text { 1- Learners are encouraged to do pair work } \\
\text { through explicit strategy of teaching request }\end{array}$} & - & - & & 1 & 5 & 6 \\
\hline & & & - & 16.66 & $\begin{array}{l}83.33 \\
\%\end{array}$ & \\
\hline \multirow{2}{*}{$\begin{array}{l}\text { 2- Awareness raising activities are used for } \\
\text { direct strategy of request }\end{array}$} & - & - & & 2 & 4 & 6 \\
\hline & & & - & 33.33 & $\begin{array}{l}66.67 \\
\%\end{array}$ & \\
\hline \multirow{2}{*}{$\begin{array}{l}\text { 3- Learners are encouraged to have group } \\
\text { discussion through explicit strategy of } \\
\text { teaching request }\end{array}$} & - & - & & - & 6 & 6 \\
\hline & & & - & & $100 \%$ & \\
\hline \multirow{2}{*}{$\begin{array}{l}\text { 4- Learners are provided by general } \\
\text { pragmatic, metalanguage style, cultural } \\
\text { knowledge }\end{array}$} & - & - & & 1 & 5 & 6 \\
\hline & & & - & 16.66 & $\begin{array}{l}83.33 \\
\%\end{array}$ & \\
\hline
\end{tabular}

Table 4.12

Observation scheme regarding teaching pragmatic of invitation(Spada \& Fröhlich, 1995) 


\begin{tabular}{|c|c|c|c|c|c|c|}
\hline Items & Never & Seldom & Moderate & Much & $\begin{array}{l}\text { Very } \\
\text { Much }\end{array}$ & $\mathbf{N}$ \\
\hline \multirow[t]{2}{*}{$\begin{array}{l}\text { 5- Learners are encouraged to do pair work } \\
\text { through explicit strategy of teaching genuine } \\
\text { invitations }\end{array}$} & - & - & & & $\begin{array}{l}6 \\
100 \%\end{array}$ & \\
\hline & & & - & & & 6 \\
\hline \multirow{2}{*}{$\begin{array}{l}\text { 6- Awareness raising activities are used for } \\
\text { invitation }\end{array}$} & - & - & & 1 & 5 & \\
\hline & & & & 16.66 & $\begin{array}{l}83.33 \\
\%\end{array}$ & 6 \\
\hline \multirow{2}{*}{$\begin{array}{l}\text { 7- Learners are encouraged to have group } \\
\text { discussion through explicit strategy of } \\
\text { teaching invitation }\end{array}$} & - & - & & & 6 & 6 \\
\hline & & & - & & $100 \%$ & \\
\hline \multirow{3}{*}{$\begin{array}{l}\text { 8- Learners are provided by general } \\
\text { pragmatic, metalanguage style \& cultural } \\
\text { knowledge for teaching invitation }\end{array}$} & - & - & & 2 & 4 & \\
\hline & & & & 33.33 & $\begin{array}{l}66.67 \\
\%\end{array}$ & \\
\hline & & & - & & & 6 \\
\hline
\end{tabular}

Table 4.13

Observation scheme regarding teaching pragmatic of apology(Spada \& Fröhlich, 1995)

\begin{tabular}{|c|c|c|c|c|c|c|}
\hline Items & Never & Seldom & Moderate & Much & $\begin{array}{l}\text { Very } \\
\text { Much }\end{array}$ & $\mathbf{N}$ \\
\hline \multirow[t]{2}{*}{$\begin{array}{l}\text { 9- Learners are encouraged to do pair work } \\
\text { through explicit strategy of teaching } \\
\text { acknowledgment of responsibility }\end{array}$} & - & - & & - & $\begin{array}{l}6 \\
100 \%\end{array}$ & \\
\hline & & & - & & & 6 \\
\hline \multirow{2}{*}{$\begin{array}{l}\text { 10- Awareness raising activities are used } \\
\text { for statement of the situation \& explanation } \\
\text { strategies }\end{array}$} & - & - & & 2 & 4 & \\
\hline & & & - & 33.33 & $\begin{array}{l}66.67 \\
\%\end{array}$ & 6 \\
\hline \multirow{2}{*}{$\begin{array}{l}\text { 11- Learners are encouraged to have group } \\
\text { discussion through explicit strategy of } \\
\text { teaching apology }\end{array}$} & - & - & & - & & \\
\hline & & & - & & $100 \%$ & 6 \\
\hline \multirow{2}{*}{$\begin{array}{l}\text { 12- Learners are provided by general } \\
\text { pragmatic, metalanguage style, and } \\
\text { cultural knowledge }\end{array}$} & - & - & & 2 & 4 & \\
\hline & & & - & $33.33 \%$ & $\begin{array}{l}66.67 \\
\%\end{array}$ & 6 \\
\hline
\end{tabular}


Page 31/31 